\title{
In vitro evaluation of the effects of the interaction between irrigating solutions, intracanal medication and Er:YAG laser in dentin permeability of the endodontic system
}

\section{Estudo in vitro dos efeitos da interação de substâncias irrigantes, medicação intracanal e laser Er:YAG na permeabilidade dentinária do sistema endodôntico}

\author{
Denise Pontes Raldi* \\ José Luiz Lage-Marques**
}

\begin{abstract}
The purpose of this study was to evaluate in vitro the effects of different associations between irrigating solutions (EDTA-T and citric acid), intracanal medicament (NDP), and Er:YAG laser irradiation on dentin permeability. Fifty-one extracted single-rooted teeth were instrumented and divided into seven groups. Groups GI and GII had final irrigation with a demineralizing solution only (EDTA-T and citric acid, respectively). Groups GIII and GIV had final irrigation with EDTA-T and citric acid, respectively, plus an association of irrigating solution and Er:YAG laser. Groups GV and GVI had final irrigation with EDTA-T and citric acid, respectively, plus an association of intracanal medication and Er:YAG laser. Group GVII (control group) had final irrigation with distilled water. All root canals were filled with NDP associated with rhodamine B dye. After the experimental period, the samples were transversely cut into six $2.0 \mathrm{~mm}$ thick slices for subsequent reading using the ImageLab software. Analysis of the results allowed us to conclude that there were statistically significant differences $(p<0.05)$ between the groups as to the penetration of the dye-intracanal medication solution. Groups III and IV presented smaller values of dentinal permeability when compared to the other groups. The best results were obtained with the interaction between a demineralizing irrigating solution and the association of intracanal medicament and laser Er:YAG (groups V and VI). In these groups the observed penetration of the intracanal medicament plus dye solution in the apical third was, on average, $29 \%$ greater than in the other groups.
\end{abstract}

DESCRIPTORS: Dentin permeability; Root canal irrigants; Lasers.

RESUMO: Este experimento teve como objetivo avaliar in vitro os efeitos da interação entre soluções irrigantes desmineralizadoras (EDTA-T e ácido cítrico), medicação intracanal (NDP) e laser Er:YAG na permeabilidade dentinária. Foram utilizados 51 dentes unirradiculares extraídos que, após o preparo químico-cirúrgico, foram divididos em sete grupos experimentais: grupos I e II - irrigação final com solução de EDTA-T e ácido cítrico, respectivamente; grupos III e IV - irrigação final com EDTA-T e ácido cítrico, respectivamente, mais a associação entre solução irrigante e laser Er:YAG; grupos V e VI - irrigação final com EDTA-T e ácido cítrico, respectivamente, mais a associação entre medicação intracanal e laser Er:YAG, e grupo VII (controle) - irrigação final com água destilada. Os canais radiculares foram preenchidos com o corante rodamina B solubilizado na medicação de uso intracanal NDP. Após o período experimental, as amostras foram cortadas transversalmente para posterior leitura com o software ImageLab. A análise dos resultados permitiu concluir que existiram diferenças estatisticamente significantes $(\mathrm{p}<0,05)$ quanto à penetração da solução corante-medicação intracanal nos diferentes grupos. Os grupos III e IV apresentaram menores valores de permeabilidade dentinária quando comparados aos outros e, finalmente, os melhores resultados foram obtidos quando da interação entre a solução irrigante desmineralizadora e a associação medicação intracanal/laser Er:YAG (grupos V e VI). Nesses, constatou-se que a diferença de penetração da solução corante-medicação intracanal no terço apical foi, em média, 29\% maior do que nos demais grupos.

DESCRITORES: Permeabilidade da dentina; Irrigantes do canal radicular; Lasers.

\section{INTRODUCTION}

The formation of a smear layer during chemical-surgical preparation is an undisputed fact. It is deposited on the dentinal walls and obliterates the canaliculae, thus reducing dentinal permeability.
It thus hinders penetration of chemical substances and intracanal medicaments into the dentinal mass, thereby preventing adequate cleaning and disinfection of the root canal.

For the effective removal of the smear layer, an association between sodium hypochlorite solu-

*Assistant Professor; **PhD, Professor - Discipline of Endodontics, School of Dentistry, Ibirapuera University. 
Rald DP, Lage-Marques JL. In vitro evaluation of the effects of the interaction between irrigating solutions, intracanal medication and Er: YAG laser in dentin permeability of the endodontic system. Pesqui Odontol Bras 2003;17(3):278-85.

tions and demineralizing substances (EDTA, citric acid) has been suggested. Both the organic and inorganic portions of magma would thus be acted upon. However, some studies have shown that these associations do not remove it completely, particularly when it is formed on the apical third of the root canal ${ }^{1}$.

Since the 1980s, several studies analyzing the effect of Er:YAG laser irradiation on dental tissues have been presented. As this laser emits a $2.94 \mu \mathrm{m}$ wavelength, it is highly absorbed by water and hydroxyapatite, and consequently by enamel and dentin.

When applied to dentin, this irradiation is highly absorbed and produces vaporization followed by micro explosions, causing ablation of the mineralized tissue ${ }^{12}$. Because of this property, studies have demonstrated the efficiency of the Er:YAG laser for cleaning root canal walls, vaporizing pulpal tissues, removing magma and increasing dentin permeability ${ }^{21}$. It is also noteworthy that these results have proven satisfactory even at the apical third, a less permeable root area ${ }^{13}$.

The aim of the present experiment is to evaluate in vitro the effects of the interaction of irrigating solutions employed after chemical-surgical preparation (EDTA-T and citric acid), intracanal medication and Er:YAG laser on dentin permeability.

\section{MATERIAL AND METHODS}

In our experiment, 51 single-rooted, extracted teeth were used. They were stored in $1 \%$ thymol solution until commencement of the experimental phase. Their crowns were sectioned at the enamel-cementum limit, and then hydrated in saline solution for a period of at least 72 hours.

Chemical-surgical preparation was carried out $1 \mathrm{~mm}$ short of the radiographic vertex with type-K files (up to \#40), auxiliary chemical substance Endo-PTC* and irrigation with 1\% sodium hypochlorite, according to the technique described by Paiva $\&$ Antoniazzi ${ }^{16}$ (1988). Immediately after preparation, the root canals were irrigated with $5 \mathrm{ml}$ of $1 \%$ sodium hypochlorite.
Final irrigation was then carried out with $15 \mathrm{ml}$ of $17 \%$ EDTA** $^{* *}$ solution or $15 \%$ citric acid, according to the experimental groups described below (Table 1). Irrigation time was standardized at $4 \mathrm{mi}-$ nutes. The control group was irrigated with $15 \mathrm{ml}$ of distilled water. Drying of the root canals was carried out with aspiration cannulae and absorbent paper cones.

After prior sealing of the apical foramina with utility wax, the roots were externally made impermeable with ethyl cyanoacrylate.

The salt of the dye rhodamine B was used as the disclosing solution for dentin permeability, dissolved in the solution of intracanal medication $\mathrm{NDP}^{* * *}$ at a concentration of approximately $20 \%$, following a pilot study performed prior to this experiment. The choice of the disclosing solution was based on studies ${ }^{5,7}$, in which rhodamine B was found to be effective with regard to degree of penetration and coloring of the dentin when used in association with drugs used as intracanal medication: NDP, chlorhexidine.

The root canals were filled with the dye-intracanal medication solution. After $60 \mathrm{~s}$, the solution was removed by means of suction cannulae and absorbent paper cones until there was no further trace observed. This time duration was determined on the basis of the pilot study carried out prior to this experiment. Over 24 hours - a time commonly described in the literature ${ }^{11}$ - total penetration of the dye into all the tested samples occurred. The same result was obtained over 12, 6 and 2 hours. The $60 \mathrm{~s}$ duration could be explained by the fact that the concentration of rhodamine B powder $(\cong 20 \%)$ used in this study is considerably greater than in the abovementioned studies ( $1 \%$ to $2 \%)$.

The specimens of four groups (Table 1) were irradiated by Er:YAG laser, with a wavelength of $2.94 \mu \mathrm{m}$, input pulse energy of $200 \mathrm{~mJ}$, output of $84 \mathrm{~mJ}$, repetition rate (frequency) of $6 \mathrm{~Hz}$ and average power of $1.2 \mathrm{~W}$. Total energy was $24 \mathrm{~J}$. The delivery system was a fiber optic cable $(0.375 \mathrm{~mm}$ thickness, $40 \times 28$ diameter, with two rings and a transmission factor of 0.42) coupled to a Kavo n. 2055 contra-angle handpiece (Kavo E 2055, Bi-

\footnotetext{
*Endo-PTC - ureia peroxide (10\%)/tween 80 (15\%)/carbowax (75\%) - Fórmula \& Ação Pharmacy, São Paulo, Brazil.

**EDTA-T - disodium salt of ethylenediaminetetraacetic $17 \mathrm{~g} /$ tergentol (sodium sulfate lauryldietyleneglycol ether), q. suff. 100 ml - Fórmula \& Ação Pharmacy, São Paulo, Brazil.

*** NDP - $0.32 \mathrm{~g}$ - dexamethasone phosphate/2 g paramonochlorophenol/polyethylenoglycol $400+$ rinossoro (saline solution), q. suff. 100 ml - Fórmula \& Ação Pharmacy, São Paulo, Brazil.
} 
Rald DP, Lage-Marques JL. In vitro evaluation of the effects of the interaction between irrigating solutions, intracanal medication and Er: YAG laser in dentin permeability of the endodontic system. Pesqui Odontol Bras 2003;17(3):278-85.

berach, Germany). Irradiation was delivered by the contact method, introducing the fiber-optic cable along the entire length of the root canal, irradiating the dentin wall from apical to cervical along its entire length, with helicoidal movements during approximately $5 \mathrm{~s}$ following Gutknecht et al. ${ }^{10}$ (1996). This procedure was repeated four times over approximately $20 \mathrm{~s}$, making up a total of 120 pulses.

Two groups (GIII and GIV) were irradiated with canals filled by the irrigating substance (EDTA-T or citric acid), and two further groups were irradiated after filling of the root canals with the intracanal medication-dye solution (GV and GVI). The root canals were thus filled either with an irrigating chemical substance or intracanal medication during irradiation.
Of the 51 specimens, four were used for analysis under the scanning electron microscope, and the remaining 47 specimens were divided up according to Table 1.

Using a Labcut Microtome (Extec ${ }^{\circledR}$ Labcut 1010 Low Speed Diamond Saw, Enfield, USA) seven transversal cuts were made in each specimen, of a standard $2.0 \mathrm{~mm}$ thickness, which resulted in six slices: two from the cervical third ( $\mathrm{C} 1$ and $\mathrm{C} 2)$, two from the medial third (C3 and $\mathrm{C} 4$ ), and two from the apical third (C5 and C6). The first two slices corresponding to the cervical and apical thirds were ignored.

The images of the dyed slices were digitalized using the ImageLab 2.3 software* to assess the penetration of the dye-intracanal medication solution by measurement of the dyed area. The percen-

TABLE 1 - Distribution of the 47 specimens according to treatment performed.

\begin{tabular}{c|l}
\hline \hline Group I (7 specimens) & Final irrigation with EDTA-T + solution of rhodamine B-intracanal medication NDP \\
\hline Group II (7 specimens) & Final irrigation with citric acid + solution of rhodamine B-intracanal medication NDP \\
\hline Group III (7 specimens) & $\begin{array}{l}\text { Final irrigation with EDTA-T + association of EDTA-T/Er:YAG laser + solution of } \\
\text { rhodamine B-intracanal medication NDP }\end{array}$ \\
\hline Group IV (7 specimens) & $\begin{array}{l}\text { Final irrigation with citric acid + association of citric acid/Er:YAG laser + solution of } \\
\text { rhodamine B-intracanal medication NDP }\end{array}$ \\
\hline Group V (7 specimens) & $\begin{array}{l}\text { Final irrigation with EDTA-T + association of solution of rhodamine B-intracanal me- } \\
\text { dication NDP/Er:YAG laser }\end{array}$ \\
\hline Group VI (7 specimens) & $\begin{array}{l}\text { Final irrigation with citric acid + association of solution of rhodamine B-intracanal } \\
\text { medication NDP/Er:YAG laser }\end{array}$ \\
\hline Group VII (5 specimens) & $\begin{array}{l}\text { Control - final irrigation with distilled water + solution of rhodamine B-intracanal me- } \\
\text { dication NDP }\end{array}$ \\
\hline \hline
\end{tabular}

TABLE 2 - Percentual averages of penetration of the dye-intracanal medication solution in the cervical, medial and apical thirds of the experimental groups.

\begin{tabular}{l|c|c|c}
\hline \hline & Cervical third $\left(\frac{\mathrm{C} 1+\mathrm{C} 2}{2}\right)$ & Medial third $\left(\frac{\mathrm{C} 3+\mathrm{C} 4}{2}\right)$ & Apical third $\left(\frac{\mathrm{C} 5+\mathrm{C} 6}{2}\right)$ \\
\hline Group I (EDTA-T) & 77.5 & 55.0 & 20.2 \\
\hline Group II (citric acid) & 84.1 & 56.3 & 21.3 \\
\hline Group III (EDTA-T + Er:YAG) & 72.0 & 51.2 & 18.4 \\
\hline Group IV (citric acid + Er:YAG) & 61.3 & 42.6 & 17.2 \\
\hline $\begin{array}{l}\text { Group V (EDTA + intracanal medi- } \\
\text { cation + Er:YAG) }\end{array}$ & 74.7 & 74.7 & 49.5 \\
\hline $\begin{array}{l}\text { Group VI (citric acid + intracanal } \\
\text { medication + Er:YAG) }\end{array}$ & 78.5 & 71.9 & 45.5 \\
\hline Control & 59.5 & 37.9 & 15.8 \\
\hline \hline
\end{tabular}

*ImageLab 2.3 - software developed by the Dentistry Informatics Laboratory, School of Dentistry, University of São Paulo. 
Rald DP, Lage-Marques JL. In vitro evaluation of the effects of the interaction between irrigating solutions, intracanal medication and Er: YAG laser in dentin permeability of the endodontic system. Pesqui Odontol Bras 2003;17(3):278-85.

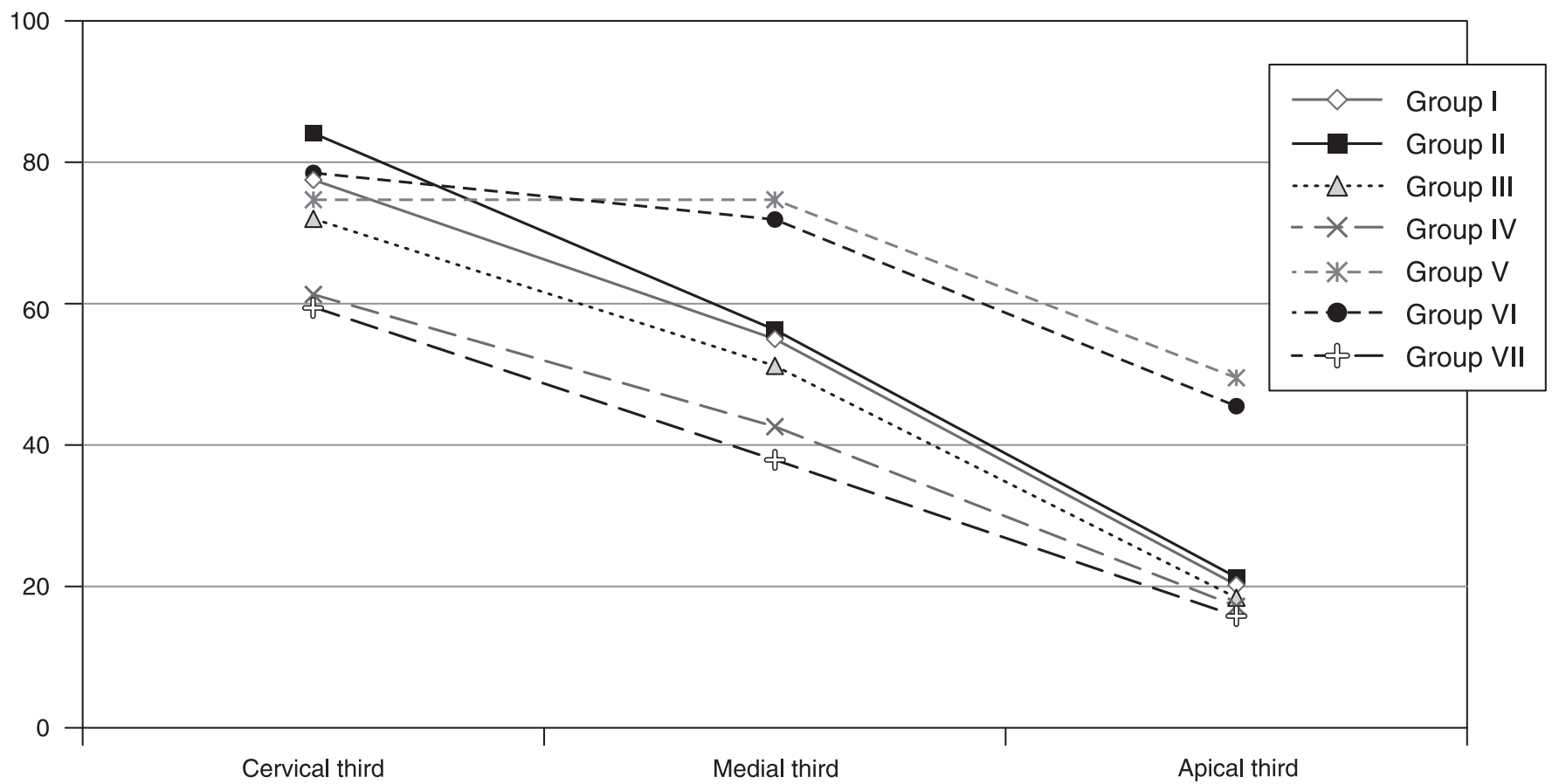

GRAPH 1 - Percental averages of penetration of the dye-intracanal medication solution in the cervical, medial and apical thirds of the specimens.

tage of the dyed area in relation to the total radicular area was calculated for each cut.

\section{RESULTS}

The results obtained are set out in Table 2 and Graph 1 and represent the average penetration, as a percentage, of the rhodamine B dye - NDP intracanal medication solution, respectively in the cervical, medial and apical thirds.

The results of the statistical analysis by the Kruskal-Wallis test, at a level of significance of 5\%, are presented on Table 3.

Results of scanning electron microscopy for specimens of Group III and IV (500 X magnification) are presented in Figures 1, 2 and 3.

\section{DISCUSSION}

Groups I and II (specimens treated with irrigating substances EDTA-T or citric acid) presented superior results in comparison with the control group, with a statistically significant difference for the penetration of the dye-intracanal medication solution in the cervical and medial thirds (Table 3). These results are borne out in present literature ${ }^{8-9}$, in which the use of demineralizing irrigating solutions is reported as helping in the cleaning of root canals since they act on the inorganic portion of the canal's contents increasing dentin permeability and thus enabling a freer passage of medications and solutions through the dentinal tubules ${ }^{6}$.

It is noteworthy that these differences, in most studies, are minor and not statistically significant. They are justified by possible variations both in the evaluation methodology and in the concentrations of chelating substances and $\mathrm{pH}$ of the solutions in question.

The fact that there is no difference in penetration of the dye-intracanal medication solution in the apical third between groups I, II and the control group might be explained by the fact that the region is the least permeable owing to its anatomical conditions, as well as the most refractory to the action of instruments and therefore the most critical in terms of cleanliness and the formation of dentinal magma.

In groups III and IV specimens, penetration of the dye-intracanal medication solution was greater than in the control group. However, it was less than in the non-irradiated specimens, groups I and II (Table 1). These differences were unexpected in that several studies have shown greater cleaning of the walls of root canals when irradiated with Er:YAG laser (Key II ${ }^{\oplus}$, Kavo, Biberach, Germany - Laboratório Experimental de Laser em 
Rald DP, Lage-Marques JL. In vitro evaluation of the effects of the interaction between irrigating solutions, intracanal medication and Er: YAG laser in dentin permeability of the endodontic system. Pesqui Odontol Bras 2003;17(3):278-85.

Odontologia do Departamento de Dentística da Faculdade de Odontologia da Universidade de Sao Paulo. This is because the laser causes ablation of the dentinal tissue, removal of dentinal magma and opening of the dentinal tubules ${ }^{20,21}$. Better results were therefore expected when associating demineralizing substances with laser irradiation.

In the present study, as with those by Pécora et al. ${ }^{18}(2000)$ and Brugnera Junior ${ }^{3}(2000)$, there may presumably have been interaction between the Er:YAG laser and the irrigating substances used, which interfered in the absorption of the laser energy by the dentinal tissue and in the values of dentin permeability to the dye-intracanal medication solution.

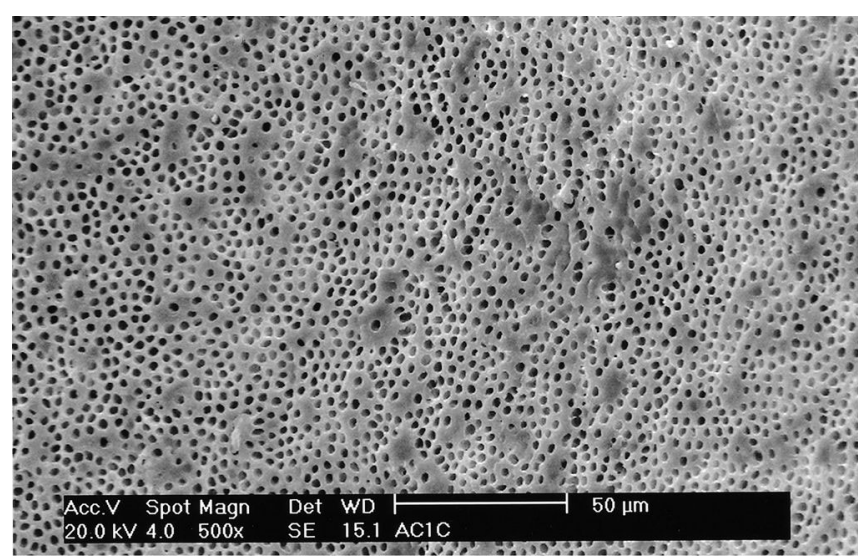

FIGURE 1 - View of cervical third, aspect of the dentin, after treatment with citric acid + Er:YAG (Group IV). Note the entrances of unobstructed dentinal tubules and absence of smear layer.

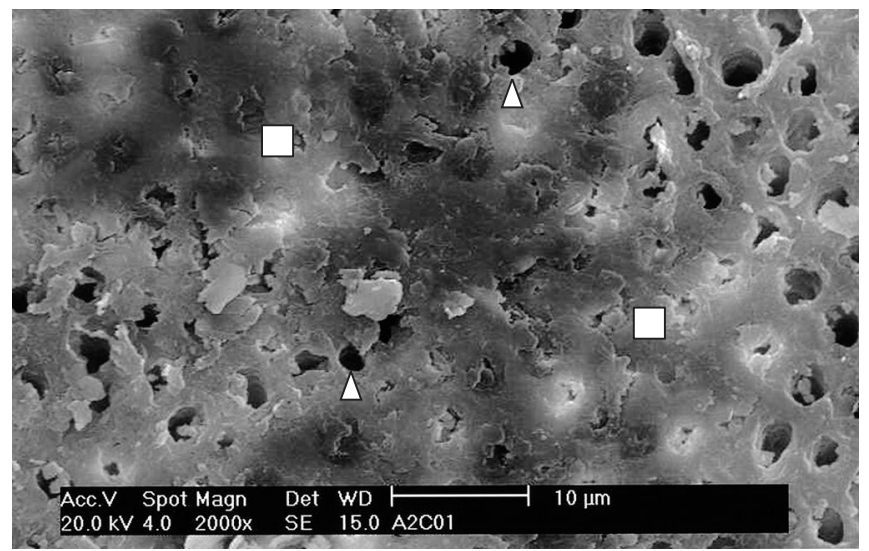

FIGURE 2 - View of medial third, aspect of the dentin, after treatment with citric acid + Er:YAG. $\square$ Areas with deficient cleaning - entrances of dentinal tubules obstructed by smear layer. $\triangle$ Clean areas - entrances of open dentinal tubules.
This interaction has been ascribed to the high ionic conductance of the substances in question, which, owing to their possessing a large quantity of free ions and different absorption peaks from the Er:YAG laser, prompted dispersion of laser irradiation, causing it to hit the target tissue with altered intensity, reducing its absorption and therefore its effects $^{19}$.

One factor that might be questioned in this study is the thermal effect generated by laser irradiation, since water jets were not used during application and studies have shown that cooling enhances the effectiveness of laser irradiation (degree of ablation of hard dental tissue) and mitigates damaging effects ${ }^{15,17}$. Two precautions were therefore taken: at the moment of irradiation the

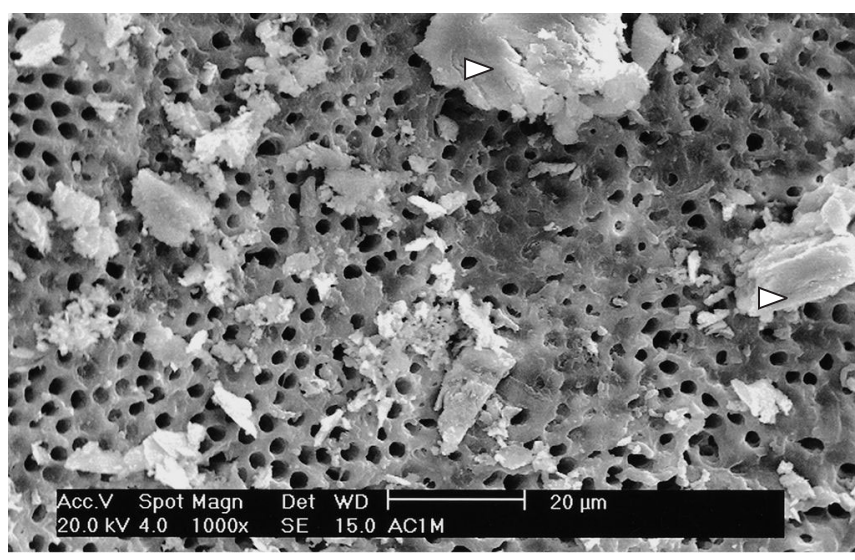

FIGURE 3 - View of the medial third, aspect of the dentin, after treatment with citric acid and Er:YAG (group IV). $\triangleright$ White crystalline particles.

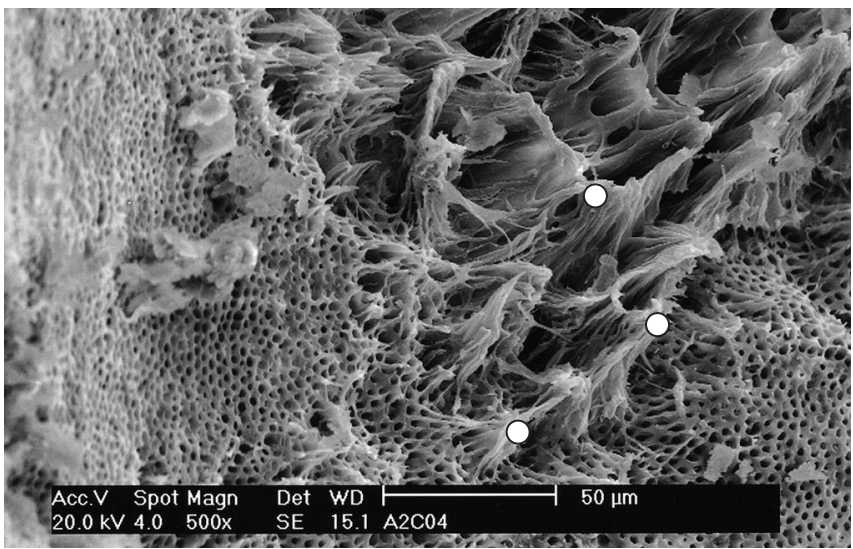

FIGURE 4 - View of the cervical third, with evident morphologic change of the dentin after irradiation with Er:YAG laser observed in specimen of group III (EDTA-T + Er:YAG). O Melting and recrystallization zones in dentin - "bulletscoring" aspect. 
Rald DP, Lage-Marques JL. In vitro evaluation of the effects of the interaction between irrigating solutions, intracanal medication and Er: YAG laser in dentin permeability of the endodontic system. Pesqui Odontol Bras 2003;17(3):278-85.

TABLE 3 - Differences between penetration averages for the dye-intracanal medication solution in the cervical, medial and apical thirds of the experimental groups and the results of the Kruskal-Wallis test.

\begin{tabular}{|c|c|c|c|c|c|c|}
\hline \multicolumn{7}{|c|}{ Cervical third } \\
\hline & GII (84.1) & GIII (72) & GIV (61.3) & GV (74.7) & GVI (78.5) & GVII (59.5) \\
\hline GI $\quad(77.5)$ & 6.6 & 5.5 & 16.2 & 2.8 & 1.0 & 18 \\
\hline GII (84.1) & & 12.1 & 22.8 & 9.4 & 5.6 & 24.6 \\
\hline GIII (72) & & & 10.7 & 2.7 & 6.5 & 12.5 \\
\hline GIV (61.3) & & & & 13.4 & 17.2 & 1.8 \\
\hline GV $\quad(74.7)$ & & & & & 3.8 & 15.2 \\
\hline GVI (78.5) & & & & & & 19 \\
\hline \multicolumn{7}{|c|}{ Medial third } \\
\hline & GII (56.3) & GIII (51.2) & GIV (42.6) & GV (74.7) & GVI (71.9) & GVII (37.9) \\
\hline GI (55) & 1.3 & 3.8 & 12.4 & 19.7 & 16.9 & 17.1 \\
\hline GII (56.3) & & 5.1 & 13.7 & 18.4 & 15.6 & 18.4 \\
\hline GIII (51.2) & & & 8.6 & 23.5 & 20.7 & 13.3 \\
\hline GIV (42.6) & & & & 32.1 & 29.3 & 4.7 \\
\hline GV $(74.7)$ & & & & & 2.8 & 36.8 \\
\hline GVI (71.9) & & & & & & 34 \\
\hline \multicolumn{7}{|c|}{ Apical third } \\
\hline & GII (21.3) & GIII (18.4) & GIV (17.2) & GV (49.5) & GVI (45.5) & GVII (15.8) \\
\hline GI $(20.2)$ & 1.1 & 1.8 & 3 & 29.3 & 25.3 & 4.4 \\
\hline GII (21.3) & & 2.9 & 4.1 & 28.2 & 24.2 & 5.5 \\
\hline GIII (18.4) & & & 1.2 & 31.1 & 27.1 & 2.6 \\
\hline GIV (17.2) & & & & 32.3 & 28.3 & 1.4 \\
\hline GV (49.5) & & & & & 4 & 33.7 \\
\hline GVI (45.5) & & & & & & 29.7 \\
\hline
\end{tabular}

Non-significant. $\square$ Significant at $5 \%(\alpha=0.05)$.

canals were filled with the irrigating substance or the dye-intracanal medication solution, and the rate of repetition (frequency) was reduced to $6 \mathrm{~Hz}$, because it has been observed that the effect of an increased frequency rate of laser emission on the temperature curve is very pronounced in comparison to an equivalent increase in incident energy ${ }^{12}$.

In order to better elucidate the results obtained with groups III and IV, it was decided that two specimens from each group should be analyzed under scanning electron microscopy. In the tested samples, areas of dentin that were totally free of debris and that had open dentinal tubules were found (Figure 1); these findings are the most commonly seen in groups irradiated with Er:YAG laser ${ }^{13,20,21}$. Areas with morphological changes (melting and resolidification) indicative of laser irradiation were found (Figure 2).
Both in group III and in group IV, as with the studies of Miserendino et al. ${ }^{14}$ (1995), white crystalline particles were found deposited on the walls of the root canals, which had open dentinal tubules (Figure 3). The presence of these particles as well as nuclei of crystallization (Figure 4) in different regions of the irradiated dentin may possibly account for the reduced penetration of the dye-intracanal medication solution.

Groups V and VI, when compared with the remaining groups, showed much superior results, above all in the medial and apical thirds (Tables 2 and 3). Penetration of the dye-intracanal medication solution in the apical third was on average $29 \%$ higher than in the remaining groups.

These results are extremely important given the ceaseless pursuit of greater cleaning and disinfection of the endodontic system, especially in this region, which, as has been mentioned, is most criti- 
Rald DP, Lage-Marques JL. In vitro evaluation of the effects of the interaction between irrigating solutions, intracanal medication and Er: YAG laser in dentin permeability of the endodontic system. Pesqui Odontol Bras 2003;17(3):278-85.

cal and less permeable to penetration by irrigating substances and intracanal medication ${ }^{1}$.

This significant increase in penetration of intracanal medication caused by irradiation by Er:YAG laser is, from a clinical point of view, extremely applicable, especially in cases of resistant and refractory infections in which the micro-organisms (facultative aerobes and anaerobes) propagate into deeper regions of the endodontic system.

With regard to the superior results obtained in groups V and VI, this may be explained by the mechanical effect stemming from the interaction of laser irradiation with the target tissue. This effect may result from the formation of shock waves from the production of photons in the irradiated tissue ${ }^{2}$. In this case, irradiation with Er:YAG laser of root canals filled with the dye-intracanal medication solution may have provoked a "micro-explosion" of the solution into the dentinal tubules. During irradiation of the specimens of these groups, this action was visually confirmed since the dye-intracanal medication solution could be seen being thrown in several directions.

The results obtained in this experiment allow us to state that Er:YAG laser proved effective as a coadjuvant in the medication phase of endodontic treatment, providing better penetration of the in-

\section{REFERENCES}

1. Aktener BO, Bilkay U. Smear layer removal with different concentrations of EDTA. J Endod 1993;49:228-31.

2. Bachmann L. Sistema de entrega de feixe para laser de hólmio e aplicações em Endodontia [Dissertação de Mestrado]. São Paulo: Instituto de Pesquisas Energéticas e Nucleares da USP; 2000.

3. Brugnera Jr A. Estudo da ação dos lasers Er:YAG e Nd:YAG sobre a permeabilidade da dentina das paredes dos canais radiculares instrumentados [Tese de Doutorado]. Rio de Janeiro: Faculdade de Odontologia da UFRJ; 2000.

4. Cecchini SCM. Estudo in vitro das aplicações do laser Hólmio:YLF em esmalte e dentina, visando a realização de cirurgia de acesso endodôntico e preparo cavitário [Dissertação de Mestrado]. São Paulo: Instituto de Pesquisas Energéticas e Nucleares da USP; 1995.

5. Fidel SR, Lage-Marques JL, Antoniazzi JH. Avaliação da capacidade de penetração dentinária radicular da chlorhexidine associada a três diferentes veículos. RPG Rev Pós Grad 1995;2:121-6.

6. Foster KH, Kulild JC, Weller RN. Effect of smear layer removal on the diffusion of calcium hydroxide through radicular dentin. J Endod 1993;19:136-40.

7. Fróis I. Análise in vitro da capacidade de penetração dentinária de alguns fármacos utilizados na medicação intracanal [Dissertação de Mestrado]. São Paulo: Faculdade de Odontologia da USP; 1989. tracanal medication into the root canal system. However, it should be pointed out that experiments evaluating the effects of Er:YAG laser irradiation on root canals are very recent, which is why varying and peculiar results have been obtained. Further studies should therefore be performed in order to better elucidate these interactions.

\section{CONCLUSIONS}

In light of what has been stated here, and of the results obtained, we feel it relevant to conclude that:

1. Final irrigation with demineralizing substances (EDTA-T and citric acid) enhanced dentinal permeability.

2. Interaction between the demineralizing irrigating substances (EDTA-T and citric acid) and Er:YAG laser was unfavorable and inefficient in enhancing dentinal permeability.

3. The interaction between demineralizing substance + association of intracanal medication and Er:YAG laser was efficient and promoted the greatest rates of permeability in all the root thirds, the permeability in the apical third being on average $29 \%$ greater than in the remaining groups.

8. Gaberoglio R, Becce C. Smear layer removal by root canal irrigants. A comparative scanning electron microscopic study. Oral Surg Oral Med Oral Pathol 1994;78:359-67.

9. Goldman M, Goldman LB, Cavaleri R, Lin PS. The efficacy of several endodontic irrigating solutions: a scanning electron microscopic study: part 2. J Endod 1982;8:487-92.

10. Gutknecht N, Kaiser F, Hassan A, Lampert F. Long-term clinical evaluation of endodontically treated teeth by Nd:YAG lasers. J Clin Laser Med Surg 1996;14(1):7-11.

11. Hamaoka L, Moura AAM. Avaliação in vitro da permeabilidade dentinária radicular, tendo como fonte de variação três diferentes tipos de corantes. Rev Odontol Univ São Paulo 1996;10:30-42.

12. Hibst R, Keller U. Heat effect of pulsed Er:YAG laser radiation (1990) apud Cecchini SCM. Estudo in vitro das aplicações do laser Hólmio:YLF em esmalte e dentina, visando a realização de cirurgia de acesso endodôntico e preparo cavitário [Dissertaçao de Mestrado]. São Paulo: Instituto de Pesquisas Energéticas e Nucleares da USP; 1995.

13. Matsuoka E, Kimura Y, Matsumoto K. Studies on the removal of debris near the apical seats by Er:YAG laser and assessment with a fiberscope. J Clin Laser Med Surg, 1998;18:255-61.

14. Miserendino LJ, Levy GC, Rizoiu IM. Effect of Nd:YAG laser on the permeability of root canal wall dentin. J Endod 1995;21:83-7. 
Rald DP, Lage-Marques JL. In vitro evaluation of the effects of the interaction between irrigating solutions, intracanal medication and Er: YAG laser in dentin permeability of the endodontic system. Pesqui Odontol Bras 2003;17(3):278-85.

15. Paghdiwala AF. Root resection of endodontically treated teeth by Erbium:YAG laser radiation. J Endod 1993;19:91-4.

16. Paiva JG, Antoniazzi JH. Fase do preparo do canal radicular. In: Endodontia: bases para a prática clínica. $2^{a}$ ed. São Paulo: Artes Médicas; 1988. p. 531-629.

17. Pécora JD, Brugnera Jr A, Cussioli AL, Zanin F, Marchesan MA, Daghastnli NS, et al. Effect of energy $(\mathrm{J})$ on the temperature changes at the apical root surface when using Er:YAG laser to enlarge root canal. Laser in Dentistry VI 2000;1:90-4.

18. Pécora JD, Brugnera Jr A, Cussioli AL, Zanin F, Silva R. Evaluation of dentin root canal permeability after instrumentation and Er:YAG laser application. Lasers Surg Med 2000;26:277-81.
19. Ribeiro RG. Estudo da permeabilidade dentinária das paredes dos canais radiculares instrumentados com diferentes soluções irrigantes, associadas ou não à irradiação de laser Er:YAG [Dissertação de Mestrado]. Ribeirão Preto: Faculdade de Odontologia da USP; 2001.

20. Takeda FH, Harashima T, Kimura Y, Matsumoto K. Efficacy of Er:YAG laser irradiation in removing debris and smear layer on root canal walls. J Endod 1998; 24:548-51.

21. Takeda FH, Harashima T, Kimura Y, Matsumoto K. A comparative study of the removal of smear layer by three endodontic irrigants and two types of laser. Int Endod $\mathrm{J}$ 1999;32:32-9.

Recebido para publicação em 16/09/02

Enviado para reformulação em 21/02/03

Aceito para publicação em 07/04/03

\section{This article has received corrections in agreement with the ERRATUM published in Volume 17 Number 4.}

